\title{
Bronchial Reactivity, Inflammatory and Allergic Parameters, and Vitamin D Levels in Children With Asthma
}

\author{
Husein Dabbah MD, Ronen Bar Yoseph MD, Galit Livnat MD, Fahed Hakim MD, \\ and Lea Bentur MD
}

\begin{abstract}
BACKGROUND: A low serum vitamin D level may represent a marker of other perplexing factors that may lead to increased asthma prevalence and severity. Our aim was to assess the correlation between vitamin D levels and asthma and allergy markers in a subgroup of children with fewer confounding factors. METHODS: Non-obese children (6-18 y old) with asthma who were not receiving anti-inflammatory treatment were recruited. Subjects underwent spirometry with a methacholine challenge test, and fractional exhaled nitric oxide $\left(\mathbf{F}_{\mathrm{ENO}}\right)$, serum vitamin $\mathrm{D}$ levels, total immunoglobulin $\mathbf{E}$ (IgE) levels, blood eosinophil counts, and high-sensitivity C-reactive protein levels were determined. The primary end point was the correlation between vitamin $\mathrm{D}$ level and airway hyper-responsiveness as assessed by a methacholine challenge test. The secondary end point was the correlation between vitamin $\mathrm{D}$ level and $\mathbf{F}_{\text {ENO }}$, systemic inflammatory markers, and allergy. RESULTS: Seventy-one children with asthma (25 females, $35 \%$; $12.5 \pm 3.6 \mathrm{y}$ of age) were included. The median vitamin D level was $23 \mathrm{ng} / \mathrm{mL}$ (range of 6-48.5, mean of $23.02 \pm 7.74$ ), the median IgE level was $305 \mathrm{IU} / \mathrm{mL}$ (range of 4.3-4,240), the median provocational concentration of methacholine that produced a $20 \%$ decrease in $\mathrm{FEV}_{1}$ was $1.1 \mathrm{mg} / \mathrm{mL}$ (range of 0-13.9), and the median $F_{E N O}$ was $26.5 \mathrm{ppb}$ (range of 3.6-285). No correlation was found between vitamin $D$ level and response to the methacholine challenge test, $\mathrm{F}_{\mathrm{ENO}}$, high-sensitivity $\mathrm{C}$-reactive protein levels, IgE levels, eosinophil counts, and frequency of allergic rhinitis or atopic dermatitis. CONCLUSIONS: In our group of children with asthma, no correlation was found between the level of vitamin $D$ and the degree of airway reactivity, airway inflammation, and allergy. The cause-and-effect relationship between vitamin $D$, asthma, and allergy should be further clarified. (ClinicalTrials.gov registration NCT01287455) Key words: vitamin D; airway hyper-responsiveness; fractional exhaled NO; high-sensitivity C-reactive protein; asthma; allergic parameters. [Respir Care 2015;60(8):1157-1163. (c) 2015 Daedalus Enterprises]
\end{abstract}

\section{Introduction}

Asthma is a chronic inflammatory disorder characterized by increased airway hyper-responsiveness (AHR) and

Dr Dabbah is affiliated with the Department of Pediatrics, Galilee Medical Center, Nahariya, Israel, and the Faculty of Medicine in the Galilee, Bar-Ilan University, Safed, Israel. Drs Bar Yoseph, Livnat, Hakim, and Bentur are affiliated with the Pediatric Pulmonology Unit, Meyer Children's Hospital, Rambam Health Care Campus, Haifa, Israel. Dr Bentur is also affiliated with the Rappaport Faculty of Medicine, TechnionIsrael Institute of Technology, Haifa, Israel.

Drs Dabbah and Bar Yoseph, are co-first authors.

Dr Bar Yoseph presented a version of this paper at the 13th International Congress on Pediatric Pulmonology, held June 26-29, 2014, in Bruges, Belgium. variable air-flow obstruction. ${ }^{1}$ The inflammatory process in asthma is assumed to be a T helper cell type 2 (Th2)driven process that enhances eosinophil accumulation and immunoglobulin (IgE) production, leading to AHR..$^{2,3}$ Asthma prevalence is rising in both the developed and the developing world, with an estimation of $>300$ million people affected worldwide. ${ }^{4,5}$

\footnotetext{
This study was supported by a research grant from Novartis. The authors have disclosed no conflicts of interest.

Correspondence: Husein Dabbah MD. E-mail: h_dabbah@rambam. health.gov.il.

DOI: $10.4187 /$ respcare. 03763
} 


\section{Vitamin D AND Asthma}

Many potential factors and reasons have been suggested to lead to the increasing prevalence of asthma; it has been proposed that vitamin $\mathrm{D}$ deficiency may explain a portion of the asthma epidemic. Vitamin D is a preprohormone that has 2 parent forms: cholecalciferol (vitamin $\mathrm{D}_{3}$ ) and ergocalciferol (vitamin $\mathrm{D}_{2}$ ). Cholecalciferol is synthesized in human skin from its precursor upon exposure to sunlight and may also be ingested in the diet (primarily from eating oily fish). Ergocalciferol is the plant and fungal form of the vitamin, which may occasionally be ingested in the diet primarily by eating fungi. Vitamin D deficiency is one of the most prevalent medical conditions and is spreading worldwide. ${ }^{6}$ Indeed, previous studies reported a high burden of vitamin D deficiency even in sun-replete areas. ${ }^{7,8}$ Case-control studies addressing the interconnection between vitamin $\mathrm{D}$ and asthma showed that children with asthma had a higher prevalence of vitamin D deficiency compared with control subjects. ${ }^{9}, 10$ Moreover, epidemiologic studies implicated the role of vitamin D deficiency in allergy and asthma development and exacerbations. ${ }^{11-14}$ In a large cohort of Costa Rican children with asthma, an inverse relation between the serum vitamin D levels and the total IgE levels and eosinophil counts was demonstrated. ${ }^{15}$ Other studies have shown that low serum vitamin D levels are associated with reduced lung function in adolescents, ${ }^{16}$ poor asthma control, ${ }^{17}$ and the presence of exercise-induced bronchoconstriction in children with asthma. ${ }^{18} \mathrm{~A}$ recent study showed increased levels of vitamin D-binding protein and 25-hydroxyvitamin D in bronchoalveolar lavage fluid after allergen challenge, suggesting a role for these factors in allergic late-phase reactions. ${ }^{19}$

A low serum vitamin D level may represent a marker of Western life style. Modern life is associated with less time spent outdoors; altered nutrition; increased obesity; exposure to cigarette smoking, ultrafine particles, and ozone; and inadequate physical activity. These factors are linked to increased asthma prevalence and increased severity. Nonobese children with asthma who are not receiving antiinflammatory drugs may represent a specific subgroup with fewer confounding factors. The aim of this study was to examine the relationship between serum vitamin $\mathrm{D}$ levels and AHR, fractional exhaled nitric oxide $\left(\mathrm{F}_{\mathrm{ENO}}\right)$, highsensitivity C-reactive protein levels, and allergy markers in a specific subgroup of children with asthma.

\section{Methods}

\section{Study Population}

Children (6-18 y old) with controlled or partially controlled asthma as defined by Global Initiative for Asthma guidelines ${ }^{1}$ were included if they were not receiving preventive anti-inflammatory drugs ( $>2$ weeks), bronchodi-

\section{QUICK LOOK}

\section{Current knowledge}

Asthma is a chronic inflammatory disorder characterized by increased airway hyper-responsiveness and variable air-flow obstruction and affects over 300 million people worldwide. A low serum vitamin D level may represent a marker of factors leading to increased asthma prevalence and severity.

\section{What this paper contributes to our knowledge}

In a group of 71 children with asthma, no correlation was found between the level of vitamin D and the degree of airway reactivity, airway inflammation, and allergy. Importantly, $<20 \%$ of subjects had sufficient vitamin $\mathrm{D}$ levels despite adequate nutritional status and exposure to sunlight.

lators $(>24 \mathrm{~h})$, or systemic corticosteroids ( $>2$ months). Exclusion criteria were: obesity defined by body mass index above the 85th percentile for age and $\mathrm{sex}^{20}$; any chronic illness, respiratory infection, or emergency room visit 2 months before study initiation; acute illness; or $\mathrm{FEV}_{1}<65 \%$ on the study day.

Demographics and personal and family history of respiratory disease, allergic symptoms, and smoking were recorded. Spirometry with a methacholine challenge test was performed, and $\mathrm{F}_{\mathrm{ENO}}$, serum vitamin $\mathrm{D}$ levels, total $\mathrm{IgE}$ levels, peripheral blood eosinophil counts, and high-sensitivity C-reactive protein levels were evaluated. This study was approved by the Rambam Medical Center institutional review committee (number 483-10) and registered at the National Institutes of Health (NCT01287455). All parents signed an informed consent before their children entered the study.

\section{Vitamin D Status}

A single measurement of serum vitamin D concentration (measured as 25-hydroxyvitamin D) was performed using a radioimmunoassay method. Values were categorized as sufficient $(>30 \mathrm{ng} / \mathrm{mL})$, insufficient $(20-30$ $\mathrm{ng} / \mathrm{mL})$, and deficient $(<20 \mathrm{ng} / \mathrm{mL})$ on the basis of previous recommendations. ${ }^{21}$

\section{Pulmonary Function Testing}

Spirometry was conducted in accordance with American Thoracic Society recommendations ${ }^{22}$ using a KoKo spirometer (nSpire Health, Longmont, Colorado). The best $\mathrm{FEV}_{1}$ and FVC were selected for data analysis. Subjects 


\section{Vitamin D AND Asthma}

were instructed to avoid using short-acting and long-acting bronchodilators for at least 6 and $24 \mathrm{~h}$, respectively, before evaluation. Results were expressed as percent of predicted derived from Quanjer et al. ${ }^{23}$

\section{Methacholine Challenge Test}

Subjects whose $\mathrm{FEV}_{1}$ was at least $65 \%$ of predicted on baseline spirometry underwent methacholine challenge testing at the same visit. The methacholine challenge test was performed according to American Thoracic Society guidelines using triple concentrations of methacholine (0.057-13.95 mg). The solutions were administered using a dosimeter (nSpire Health). Nebulized methacholine was inhaled for $2 \mathrm{~min}$, with 5-min intervals between doses, until the maximal concentration or end point was reached. The provocational concentration of methacholine that produced a $20 \%$ decrease in $\mathrm{FEV}_{1}\left(\mathrm{PC}_{20}\right)$ was determined. On completion of the methacholine challenge test, $200 \mathrm{mg}$ of albuterol via an inhaler with a spacer device was given to all subjects to restore airway caliber. ${ }^{24}$

\section{$\mathbf{F}_{\text {ENO }}$}

The subjects performed 3 online single-breath maneuvers according to international guidelines ${ }^{25}$ using an Eco Medics NO analyzer (CLD 88sp F $F_{\text {ENO }}$ analyzer, Eco Physics, Dürnten, Switzerland). Blood samples were analyzed for complete blood counts and serum IgE, high-sensitivity C-reactive protein, and vitamin D levels.

\section{Statistical Analysis}

The primary end point was defined as the correlation between vitamin D levels and the degree of AHR as assessed by a methacholine challenge test in this cohort of children. The secondary end point was defined as the correlation between $\mathrm{F}_{\mathrm{ENO}}$, systemic markers of inflammation and allergy, and vitamin D levels.

The data were evaluated using SPSS 18 (SPSS, Chicago, Illinois). The Kolmogorov-Smirnov test was used to assess normal distribution of the variables. Logarithmic transformation of the data was done whenever the distribution was highly skewed. The Mann-Whitney $U$ test, $t$ test, and analysis of variance were applied to compare differences between vitamin D levels and numerical parameters. Pearson correlation was used for quantitative variables. A chi-square test was performed to determine correlation between categorical variables (sex, smoking, season, allergy). $P<.05$ was considered significant. A sample size of at least 20 children in each group was calculated to detect a 1-mg difference in $\mathrm{PC}_{20}$ between the group with vitamin $\mathrm{D}$ levels $<30 \mathrm{ng} / \mathrm{mL}$ and the group with vitamin $\mathrm{D}$ levels $>30 \mathrm{ng} / \mathrm{mL}$ (2-sided $95 \% \mathrm{CI}$, power of $80 \%$ ).
Table 1. Subject Characteristics

\begin{tabular}{|c|c|}
\hline Characteristic & Subjects $(N=71)$ \\
\hline Age, y & $12.5 \pm 3.6$ \\
\hline Female, $n(\%)$ & $25(35)$ \\
\hline BMI, $\mathrm{kg} / \mathrm{m}^{2}$ & $20.0 \pm 3.6$ \\
\hline Vitamin $\mathrm{D}, \mathrm{ng} / \mathrm{mL}$ & $23.02 \pm 7.74$ \\
\hline Total IgE, IU/mL & $305(4.3-4,240)$ \\
\hline Eosinophil count, cells $/ \mu \mathrm{L}$ & $0.38(0-4.3)$ \\
\hline $\mathrm{FEV}_{1}, \mathrm{~L}$ & $2.2(1-4.2)$ \\
\hline $\mathrm{FEV}_{1}, \%$ predicted & $89 \pm 11$ \\
\hline $\mathrm{FEV}_{1} / \mathrm{FVC}$ & $0.8(0.6-1)$ \\
\hline $\mathrm{FEF}_{25-75 \%}, \mathrm{~L} / \mathrm{s}$ & $2.2(0.8-5.3)$ \\
\hline $\mathrm{FEF}_{25-75 \%}, \%$ predicted & $81 \pm 20$ \\
\hline $\mathrm{F}_{\mathrm{ENO}}, \mathrm{ppb}$ & $26.5(3.6-285)$ \\
\hline C-reactive protein, $\mathrm{mg} / \mathrm{L}$ & $1.7(0.9-7.7)$ \\
\hline $\mathrm{PC}_{20}, \mathrm{mg} / \mathrm{mL}$ & $1.1(0-13.9)$ \\
\hline Allergic rhinitis, $n(\%)$ & $38(53.5)$ \\
\hline Atopic dermatitis, $n(\%)$ & $10(14.3)$ \\
\hline \multicolumn{2}{|c|}{$\begin{array}{l}\text { Values are given as median (interquartile range) or mean } \pm \mathrm{SD} \text { unless indicated otherwise. } \\
\mathrm{BMI}=\text { body mass index } \\
\mathrm{IgE}=\text { immunoglobulin } \mathrm{E} \\
\mathrm{FEF}_{25-75 \%} \text { = forced expiratory flow during the middle half of the } \mathrm{FVC} \text { maneuver } \\
\mathrm{F}_{\mathrm{ENO}=\text { fractional exhaled nitric oxide }} \\
\mathrm{PC}_{20}=\text { provocational concentration of methacholine that produced a } 20 \% \text { decrease in } \mathrm{FEV}_{1}\end{array}$} \\
\hline
\end{tabular}

\section{Results}

Seventy-one children with asthma referred to our Pediatric Pulmonology Unit at Meyer Children's Hospital of Rambam Health Care Campus were included in the study. All participants live in the Haifa district, in the north part of the country. The main characteristics of the subjects are reported in Table 1. All subjects had positive methacholine challenge tests $\left(\mathrm{PC}_{20}<13.95 \mathrm{mg}\right)$. Twelve subjects (16.9\%) had sufficient vitamin D levels (>30 ng/mL), 33 subjects $(46.5 \%)$ had insufficient levels $(20-30 \mathrm{ng} / \mathrm{mL})$, and 26 subjects $(36.6 \%)$ had deficient levels $(<20 \mathrm{ng} / \mathrm{mL})$ $(P<.001)$. The mean body mass index of the subjects was $20.0 \pm 3.6 \mathrm{~kg} / \mathrm{m}^{2}(<75$ th percentile and $<65$ th percentile for boys and girls, respectively). Allergic rhinitis was reported in 38 subjects $(53.5 \%)$, and $\operatorname{IgE}$ levels of $>30 \mathrm{IU} / \mathrm{mL}$ were found in 62 subjects $(87.3 \%)$. No active smoking was reported within the study population.

We did not find any correlation between serum vitamin $\mathrm{D}$ levels and $\mathrm{FEV}_{1}, \mathrm{PC}_{20}, \mathrm{~F}_{\mathrm{ENO}}$, eosinophil counts, and IgE levels in our study population (Fig. 1). When stratified to subjects with $\mathrm{FEV}_{1} \leq 80 \%$ of predicted $(n=15)$ and subjects with $\mathrm{FEV}_{1}>80 \%$ of predicted $(n=56)$, similar vitamin D levels were observed $(P=.55)$. Similarly, subjects categorized according to the degree of bronchial responsiveness as moderate or severe (methacholine challenge test $\leq 1 \mathrm{mg}, n=33$ ), mild (methacholine challenge test $\leq 4 \mathrm{mg}, n=24$ ), and borderline (methacholine challenge test $\geq 4 \mathrm{mg}, n=14$ ) had similar vitamin D levels. 


\section{VitAMin D AND Asthma}
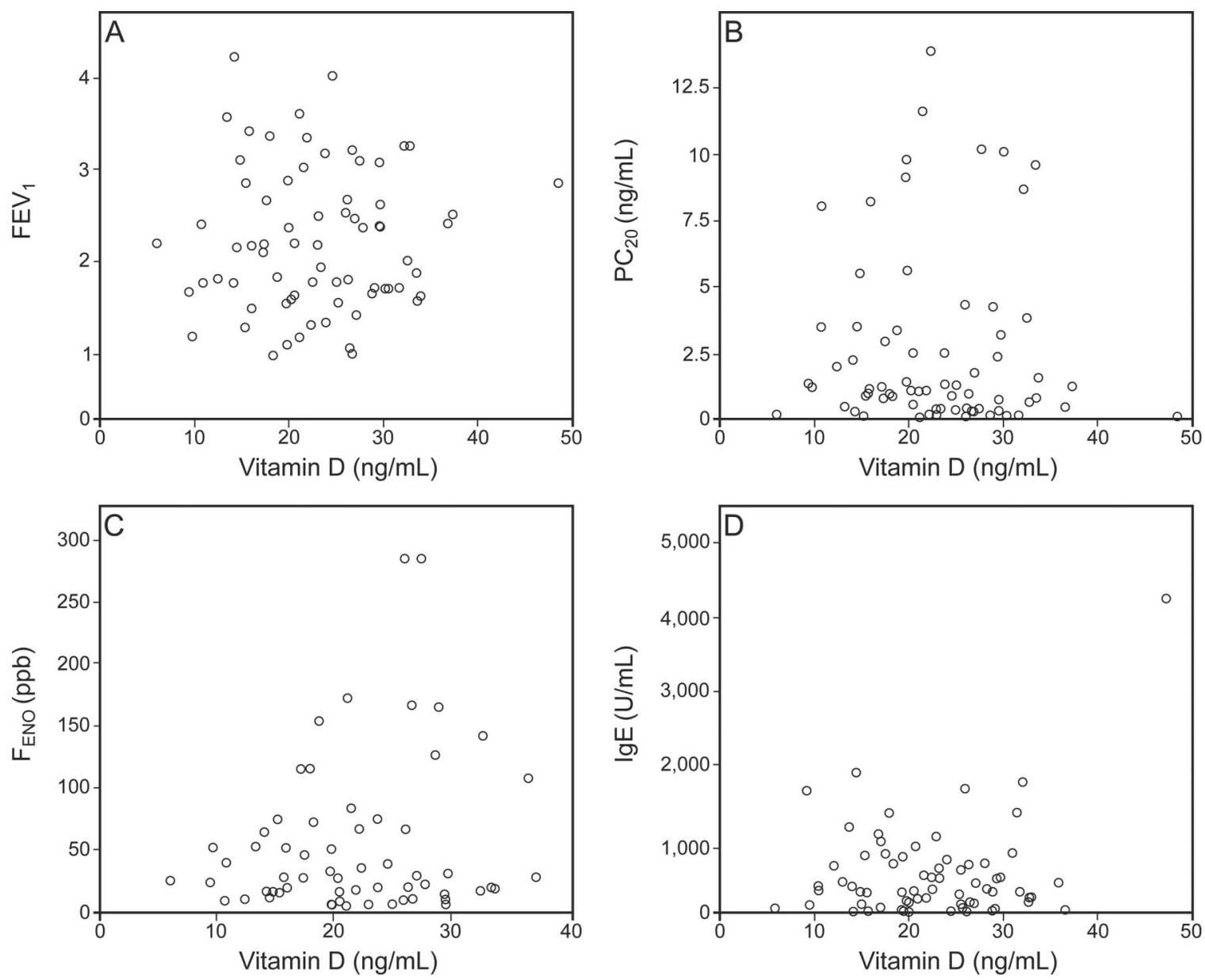

Fig. 1. Scatter plots of the relationship between serum vitamin $D$ levels and $F E V_{1}(A)$, provocational concentration of methacholine that produced a $20 \%$ decrease in $\mathrm{FEV}_{1}\left(\mathrm{PC}_{20}\right)(\mathrm{B})$, fractional exhaled nitric oxide $\left(\mathrm{F}_{\mathrm{ENO}}\right)(\mathrm{C})$, and immunoglobulin $\mathrm{E}$ (IgE) levels (D). No correlation between vitamin $\mathrm{D}$ levels and the stated parameters was found (Pearson correlation with logarithmic transformation of the data whenever the distribution was highly skewed).

Table 2 shows the main characteristics of the subjects stratified by vitamin D levels. Only 12 subjects had sufficient vitamin D levels. As shown by subgroup analysis according to vitamin $\mathrm{D}$ levels, no statistically significant difference in $\mathrm{FEV}_{1}, \mathrm{PC}_{20}, \mathrm{~F}_{\mathrm{ENO}}$, IgE levels, and eosinophil counts was found between children with vitamin D deficiency compared with children with insufficient and sufficient vitamin D levels. Subanalysis of the vitamin D-deficient group revealed no correlation between vitamin $\mathrm{D}$ and $\mathrm{F}_{\mathrm{ENO}}$, IgE levels, $\mathrm{PC}_{20}$, and $\mathrm{FEV}_{1}$ (correlation coefficient of $0.13, P=.52 ;-0.48, P=.82 ; 0.29, P=.15$; $-0.18, P=.39$, respectively).

\section{Discussion}

In our group of children with asthma, no correlation between reduced serum vitamin $\mathrm{D}$ levels and lung function, AHR, $\mathrm{F}_{\mathrm{ENO}}$, IgE levels, eosinophil counts, or C-reactive protein levels was found. Assuming that vitamin $\mathrm{D}$ deficiency is directly related to proliferation of Th2 cells, ${ }^{26,27}$ lower vitamin D levels should be related to AHR, increased $\mathrm{F}_{\mathrm{ENO}}$, IgE levels, and eosinophilia.

\section{Pulmonary Function Tests}

In contrast to previous studies, ${ }^{9-18,28-31}$ we found no correlation between serum vitamin D levels and pulmonary function. Our results are supported by studies in adults with asthma ${ }^{32}$ and studies that failed to show an association between vitamin D levels and pulmonary function, degree of asthma control, or doses of inhaled corticoids in children with asthma. ${ }^{33}$

\section{AHR}

Only a few studies have assessed the association between vitamin D deficiency and AHR. A study of 54 adults (24 on inhaled steroids) showed that reduced serum vita- 
Table 2. Subgroup Analysis According to Vitamin D Levels

\begin{tabular}{|c|c|c|c|c|}
\hline \multirow{2}{*}{ Parameter } & \multicolumn{3}{|c|}{ Vitamin D Levels } & \multirow{2}{*}{$P$} \\
\hline & $<20 \mathrm{ng} / \mathrm{mL}$ & $20-30 \mathrm{ng} / \mathrm{mL}$ & $>30 \mathrm{ng} / \mathrm{mL}$ & \\
\hline Subjects, $n(\%)$ & $26(36.6)$ & $33(46.5)$ & $12(16.9)$ & \\
\hline Age, y & $3.6 \pm 12.9$ & $3.6 \pm 12.5$ & $11.6 \pm 3.9$ & .59 \\
\hline Females, $n(\%)$ & $8(31)$ & $14(42)$ & $3(25)$ & .46 \\
\hline BMI, $\mathrm{kg} / \mathrm{m}^{2}$ & $21.2 \pm 4.4$ & $19.4 \pm 3.0$ & $19.2 \pm 2.5$ & .12 \\
\hline Vitamin $\mathrm{D}, \mathrm{ng} / \mathrm{mL}$ & $15.18 \pm 3.65$ & $25.06 \pm 3.02$ & $34.44 \pm 4.93$ & $<.001$ \\
\hline Total IgE, IU/mL & $361.5(16-1,890)$ & $260.5(4.3-1,680)$ & $433.5(37.4-4,220)$ & .06 \\
\hline Eosinophil count, cells $/ \mu \mathrm{L}$ & $0.35(0.0-0.9)$ & $0.40(0.0-4.3)$ & $0.42(0.2-1)$ & .46 \\
\hline $\mathrm{FEV}_{1}, \mathrm{~L}$ & $2.2(1-4.2)$ & $2.22(1-4)$ & $1.95(1.6-3.3)$ & .99 \\
\hline $\mathrm{FEV}_{1}, \%$ predicted & $90 \pm 13.7$ & $89 \pm 9.8$ & $85 \pm 7.5$ & .39 \\
\hline $\mathrm{FEV}_{1} / \mathrm{FVC}$ & $0.81(0.6-1)$ & $0.82(0.6-1)$ & $0.83(0.8-1)$ & .17 \\
\hline $\mathrm{FEF}_{25-75 \%}, \mathrm{~L} / \mathrm{s}$ & $1.8(0.8-5.3)$ & $2.20(0.8-4.6)$ & $2.42(1.5-3.1)$ & .89 \\
\hline $\mathrm{FEF}_{25-75 \%}, \%$ predicted & $83 \pm 17.3$ & $81 \pm 23.8$ & $78 \pm 15$ & .78 \\
\hline $\mathrm{F}_{\mathrm{ENO}}, \mathrm{ppb}$ & $29.3(4.7-153)$ & $23.7(3.6-285)$ & $22.9(16-142)$ & .59 \\
\hline C-reactive protein, $\mathrm{mg} / \mathrm{mL}$ & $1.73(0.9-6.2)$ & $1.57(0.9-4.8)$ & $1.72(1.1-7.7)$ & .34 \\
\hline $\mathrm{PC}_{20}, \mathrm{mg} / \mathrm{mL}$ & $1.33(0.1-9.8)$ & $0.86(0.1-13.9)$ & $0.99(0.1-10.1)$ & .55 \\
\hline Allergic rhinitis, $n(\%)$ & $12(46.2)$ & $20(60.6)$ & $6(50)$ & .52 \\
\hline Atopic dermatitis, $n(\%)$ & $3(11.5)$ & $4(12.5)$ & $3(25)$ & .52 \\
\hline \multicolumn{5}{|c|}{$\begin{array}{l}\text { Values are given as median (interquartile range) or mean } \pm \text { SD unless indicated otherwise. } \\
\mathrm{BMI}=\text { body mass index } \\
\mathrm{FEF}_{25-75 \%}=\text { forced expiratory flow during the middle half of the } \mathrm{FVC} \text { maneuver } \\
\mathrm{F}_{\mathrm{ENO}}=\text { fractional exhaled nitric oxide } \\
\mathrm{PC}_{20}=\text { provocational concentration of methacholine that produced a } 20 \% \text { decrease in } \mathrm{FEV}_{1}\end{array}$} \\
\hline
\end{tabular}

min D concentration was associated with greater AHR. ${ }^{34}$ A study comparing 45 children with asthma with 59 healthy control subjects found that children with asthma and exercise-induced bronchospasm had lower vitamin D levels. ${ }^{18}$ No correlation between AHR and serum vitamin D levels was observed in our cohort of 71 children with asthma. It should be noted that multivariate analysis performed in a very large cohort study in Costa Rican children with asthma failed to show a statistically significant inverse association of serum vitamin D with airway responsiveness. ${ }^{15}$ In addition, a recent study evaluating subjects with hereditary 1,25-dihydroxyvitamin D-resistant rickets (lacking the vitamin D receptor) showed protection against methacholine challenge test-provoked bronchial hyper-reactivity. ${ }^{35}$

\section{$\mathbf{F}_{\text {ENO }}$}

In our study, we failed to show any significant association between vitamin $\mathrm{D}$ levels and $\mathrm{F}_{\mathrm{ENO}}$ in children with asthma. This result is supported by a large population sample (1,315 children) that failed to demonstrate significant association between serum 25-hydroxyvitamin D levels and $\mathrm{F}_{\mathrm{ENO}},{ }^{29}$ and a recent interventional study that failed to demonstrate an effect of vitamin $\mathrm{D}$ administration on $\mathrm{F}_{\text {ENO levels. }}{ }^{36}$ It should be noted that although $\mathrm{F}_{\mathrm{ENO}}$ is considered to be a marker of eosinophilic inflammation, its value is still under debate.

C-reactive protein is a sensitive inflammatory marker that is synthesized in hepatocytes. Previous populationbased studies showed a correlation between increased levels of high-sensitivity C-reactive protein and a high frequency of AHR and low $\mathrm{FEV}_{1} \cdot{ }^{37}$ No study has evaluated $\mathrm{C}$-reactive protein in relation to serum vitamin D levels in children with asthma. No relationship between vitamin $\mathrm{D}$ levels and C-reactive protein was observed in our study.

No association between serum vitamin D levels and IgE levels or eosinophil counts was observed in our cohort of children with asthma. Our results contradict those of a previously published study showing an inverse relationship between serum vitamin D levels and total IgE levels or eosinophil counts. ${ }^{15}$ However, 2 recent studies showed similar results. ${ }^{38,39} \mathrm{We}$ suggest that these differences may be due to the small sample size and selection of subjects with milder asthma compared with subjects with more severe asthma in the other studies.

A putative explanation for the association observed between severe asthma and allergy and low serum vitamin D levels is that patients with severe asthma are more likely to spend more time indoors with less sun exposure, leading to lower serum vitamin D levels. Additionally, asthma severity is related to socioeconomic status and parental educa- 


\section{Vitamin D AND Asthma}

tion. Higher socioeconomic status may be related to a higher intake of all vitamin and nutrient supplements that could modify asthma severity, such as vitamin E supplementation. A recent study from Turkey showed that children with asthma had less exposure to sunlight and ate a diet less rich in vitamin D compared with healthy control children. ${ }^{40}$ In a recent systematic review of cohort studies concerning the association between low vitamin $\mathrm{D}$ levels and asthma in children, 3 cohort studies were eligible: 2 studies reported positive association, and the third found no association. ${ }^{41}$ The high prevalence of vitamin $\mathrm{D}$ deficiency $(36.6 \%)$ and insufficiency $(46.5 \%)$ in our group of children with asthma is in agreement with previous studies. ${ }^{10,15}$ However, it should be noted that the frequency of vitamin $\mathrm{D}$ deficiency was not assessed in a healthy control population residing in the same area.

Although most reports suggest a role for vitamin D in asthma control, others show that vitamin D may promote, rather than ameliorate, the asthma phenotype. ${ }^{42,43}$ These differences have also been reported regarding the effects of vitamin D on Th2 cell responses. One study addressing this issue reported that vitamin D supplementation through the first year of life $(2,000 \mathrm{IU} / \mathrm{d})$ elicited an increased rather than decreased risk of developing atopy, allergic rhinitis, and asthma in adulthood. ${ }^{44}$ Two recent interventional studies with vitamin D supplementation failed to show improvement in asthma control. ${ }^{36,45}$

When vitamin $\mathrm{D}$ values were categorized as sufficient ( $>30 \mathrm{ng} / \mathrm{mL})$, insufficient $(20-30 \mathrm{ng} / \mathrm{mL})$, and deficient $(<20 \mathrm{ng} / \mathrm{mL})$, similar results were observed. Of note, serum vitamin $\mathrm{D}$ cutoff levels were determined for bone health use, whereas in nonbone-related conditions, there are still no optimal levels for disease prevention. Specifically in asthma and allergy, researchers are still trying to define the serum levels of vitamin $\mathrm{D}$ that can ameliorate and prevent asthma exacerbations.

\section{Limitations}

The frequency of vitamin D deficiency was not assessed in a healthy control group. We chose children with controlled or partially controlled asthma who were not receiving treatment to perform methacholine challenge tests and to avoid the possible impact of anti-inflammatory drugs or severe asthma on vitamin D levels. Our results may be related to selection of children with asthma with few symptoms and fewer confounding factors. Alternatively, controlled or partially controlled asthma patients may have a genetic polymorphism in the vitamin $\mathrm{D}$ receptor that may be associated with better asthma control. ${ }^{46}$

Although it was a relatively large cohort, the sample size was still small and included only 12 subjects with sufficient vitamin D levels, thus limiting the statistical power. Skin tests were not performed, and allergy was assessed by history, IgE levels, and eosinophil counts. The small number of subjects with $\mathrm{FEV}_{1} \leq 80 \%$ of predicted may have precluded statistically significant change. Longterm follow-up studies focusing on changes in vitamin D status and asthma parameters are needed to clarify the effect of vitamin D status on asthma.

\section{Conclusions}

In summary, our study supports previous findings of a high prevalence of vitamin $\mathrm{D}$ deficiency in children with asthma. However, no correlation between vitamin D levels and response to a methacholine challenge test, $\mathrm{F}_{\mathrm{ENO}}$, highsensitivity C-reactive protein levels, IgE levels, and eosinophil counts was found in our cohort of children with asthma. These results emphasize the complexity of the effects of vitamin D on the immune system and its potential role in asthma prevalence and pathophysiology. More high-quality studies are needed to reliably clarify this issue, and well-designed randomized controlled trials of interventional vitamin D studies assessing supplementation with vitamin $\mathrm{D}$ or placebo in asthma are also needed.

\section{ACKNOWLEDGMENTS}

We thank Ms Ronit Leiba (Medical Statistics Unit, Rambam Health Care Campus, Haifa, Israel) for statistical help.

\section{REFERENCES}

1. Boulet LP, FitzGerald JM, Reddel HK. The revised 2014 GINA strategy report: opportunities for change. Curr Opin Pulm Med 2015; 21(1): 1-7.

2. Wagener AH, de Nijs SB, Lutter R, Sousa AR, Weersink EJ, Bel EH, Sterk PJ. External validation of blood eosinophils, $\mathrm{FE}_{\mathrm{NO}}$ and serum periostin as surrogates for sputum eosinophils in asthma. Thorax 2015;70(2):115-120.

3. Lloyd CM, Hessel EM. Functions of T cells in asthma: more than just $\mathrm{T}_{\mathrm{H}} 2$ cells. Nat Rev Immunol 2010;10(12):838-848.

4. Masoli M, Fabian D, Holt S, Beasley R. The global burden of asthma: executive summary of the GINA Dissemination Committee report. Allergy 2004;59(5):469-478.

5. Moorman JE, Rudd RA, Johnson CA, King M, Minor P, Bailey C, et al. National surveillance for asthma-United States, 1980-2004. MMWR CDC Surveill Summ 2007;56(8):1-54.

6. Holick MF. Vitamin D deficiency in 2010: health benefits of vitamin D and sunlight: a D-bate. Nat Rev Endocrinol 2011;7(2):73-75.

7. Djennane M, Lebbah S, Roux C, Djoudi H, Cavalier E, Souberbielle JC. Vitamin D status of schoolchildren in Northern Algeria, seasonal variations and determinants of vitamin D deficiency. Osteoporos Int 2014;25(5):1493-1502.

8. Vu LH, Whiteman DC, van der Pols JC, Kimlin MG, Neale RE. Serum vitamin D levels in office workers in a subtropical climate. Photochem Photobiol 2011;87(3):714-720.

9. Freishtat RJ, Iqbal SF, Pillai DK, Klein CJ, Ryan LM, Benton AS, Teach SJ. High prevalence of vitamin D deficiency among inner-city African American youth with asthma in Washington, DC. J Pediatr 2010;156(6):948-952. 


\section{VitAMin D AND Asthma}

10. Alyasin S, Momen T, Kashef S, Alipour A, Amin R. The relationship between serum 25 hydroxyvitamin $\mathrm{D}$ levels and asthma in children. Allergy Asthma Immunol Res 2011;3(4):251-255.

11. Camargo CA Jr, Rifas-Shiman SL, Litonjua AA, Rich-Edwards JW, Weiss ST, et al. Maternal intake of vitamin D during pregnancy and risk of recurrent wheeze in children at $3 \mathrm{y}$ of age. Am J Clin Nutr 2007;85(3):788-795.

12. Devereux G, Litonjua AA, Turner SW, Craig LC, McNeill G, Martindale $\mathrm{S}$, et al. Maternal vitamin $\mathrm{D}$ intake during pregnancy and early childhood wheezing. Am J Clin Nutr 2007;85(3):853-859.

13. Hollams EM, Hart PH, Holt BJ, Serralha M, Parsons F, de Klerk NH, et al. Vitamin D and atopy and asthma phenotypes in children: a longitudinal cohort study. Eur Respir J 2011;38(6):1320-1327.

14. Brehm JM, Schuemann B, Fuhlbrigge AL, Hollis BW, Strunk RC, Zeiger RS, et al. Serum vitamin D levels and severe asthma exacerbations in the Childhood Asthma Management Program study. J Allergy Clin Immunol 2010;126(1):52.e5-58.e5.

15. Brehm JM, Celedón JC, Soto-Quiros ME, Avila L, Hunninghake GM, Forno E, et al. Serum vitamin D levels and markers of severity of childhood asthma in Costa Rica. Am J Respir Crit Care Med 2009;179(9):765-771.

16. Burns JS, Dockery DW, Neas LM, Schwartz J, Coull BA, Raizenne $\mathrm{M}$, Speizer FE. Low dietary nutrient intakes and respiratory health in adolescents. Chest 2007;132(1):238-245.

17. Chinellato I, Piazza M, Sandri M, Peroni D, Piacentini G, Boner AL. Vitamin D serum levels and markers of asthma control in Italian children. J Pediatr 2011;158(3):437-441.

18. Chinellato I, Piazza M, Sandri M, Peroni DG, Cardinale F, Piacentini GL, Boner AL. Serum vitamin D levels and exercise-induced bronchoconstriction in children with asthma. Eur Respir J 2011;37(6): 1366-1370.

19. Bratke K, Wendt A, Garbe K, Kuepper M, Julius P, Lommatzsch M, Virchow JC. Vitamin D binding protein and vitamin D in human allergen-induced endobronchial inflammation. Clin Exp Immunol 2014;177(1):366-372.

20. Ogden CL, Kuczmarski RJ, Flegal KM, Mei Z, Guo S, Wei R, et al. Centers for Disease Control and Prevention 2000 growth charts for the United States: improvements to the 1977 National Center for Health Statistics version. Pediatrics 2002;109(1):45-60.

21. Searing DA, Zhang Y, Murphy JR, Hauk PJ, Goleva E, Leung DY. Decreased serum vitamin D levels in children with asthma are associated with increased corticosteroid use. J Allergy Clin Immunol 2010;125(5):995-1000.

22. American Thoracic Society. Standardization of spirometry, 1994 update. Am J Respir Crit Care Med 1995;152(3):1107-1136.

23. Quanjer PH, Borsboom GJ, Brunekreef B, Zach M, Forche G, Cotes JE, et al. Spirometric reference values for white European children and adolescents: Polgar revisited. Pediatr Pulmonol 19(2)95;19:135-142.

24. Crapo RO, Casaburi R, Coates AL, Enright PL, Hankinson JL, Irvin $\mathrm{CG}$, et al. Guidelines for methacholine and exercise challenge testing - 1999. Am J Respir Crit Care Med 2000;161(1):309-329.

25. American Thoracic Society, European Respiratory Society. ATS/ ERS recommendations for standardized procedures for the online and offline measurement of exhaled lower respiratory nitric oxide and nasal nitric oxide, 2005. Am J Respir Crit Care Med 2005; 171(8):912-930.

26. Hossein-nezhad A, Spira A, Holick MF. Influence of vitamin D status and vitamin $D_{3}$ supplementation on genome wide expression of white blood cells: a randomized double-blind clinical trial. PLoS ONE 2013;8(3):e58725.

27. Lemire JM, Archer DC, Beck L, Spiegelberg HL. Immunosuppressive actions of 1,25-dihydroxyvitamin $\mathrm{D}_{3}$ : preferential inhibition of Th1 functions. J Nutr 1995;125(6 Suppl):1704S-1708S.
28. Somashekar AR, Prithvi AB, Gowda MN. Vitamin D levels in children with bronchial asthma. J Clin Diagn Res 2014;8(10):PC04-PC07.

29. Yao TC, Tu YL, Chang SW, Tsai HJ, Gu PW, Ning HC, et al. Serum 25-hydroxyvitamin D levels in relation to lung function and exhaled nitric oxide in children. J Pediatr 2014;165(6):1098-1103.

30. Niruban SJ, Alagiakrishnan K, Beach J, Senthilselvan A. Association of vitamin D with respiratory outcomes in Canadian children. Eur J Clin Nutr 2014;68(12):1334-1340.

31. Wu AC. Effect of vitamin D and inhaled corticosteroid treatment on lung function in children. Am J Respir Crit Care Med 2012;186(6): 508-513.

32. Devereux G, Wilson A, Avenell A, McNeill G, Fraser WD. A case control study of vitamin D status and asthma in adults. Allergy 2010;65(5):666-667.

33. Krobtrakulchai W, Praikanahok J, Visitsunthorn N, Vichyanond P, Manonukul K, Pratumvinit B, Jirapongsananuruk O. The effect of vitamin D status on pediatric asthma at a university hospital, Thailand. Allergy Asthma Immunol Res 2013;5(5):289-294.

34. Sutherland ER, Goleva E, Jackson LP, Stevens AD, Leung DY. Vitamin D levels, lung function, and steroid response in adult asthma. Am J Respir Crit Care Med 2010;181(7):699-704.

35. Bar Yoseph R, Bentur L, Goldbart A, Livnat G, Hakim F, Weisman Y, Tiosano D. A mutated vitamin D receptor in hereditary vitamin D-resistant rickets prevents induction of bronchial hyperreactivity and inflammation. J Clin Endocrinol Metab 2014;99(9):E1610-E1616.

36. Bar Yoseph R, Livnat G, Schnapp Z, Hakim F, Dabbah H, Goldbart A, Bentur L. The effect of vitamin D on airway reactivity and inflammation in asthmatic children: a double-blind placebo-controlled trial. Pediatr Pulmonol 2014. doi: 10.1002/ppul.23076.

37. Sunyer J, Pistelli R, Plana E, Andreani M, Baldari F, Kolz M, et al. Systemic inflammation, genetic susceptibility and lung function. Eur Respir J 2008;32(1):92-97.

38. Yao TC, Tu YL, Chang SW, Tsai HJ, Gu PW, Ning HC, et al Suboptimal vitamin D status in a population-based study of Asian children: prevalence and relation to allergic diseases and atopy. PLoS ONE 2014;9(6):e99105.

39. Dogru M, Kirmizibekmez H, Yesiltepe Mutlu RG, Aktas A, Ozturkmen S. Clinical effects of vitamin D in children with asthma. Int Arch Allergy Immunol 2014;164(4):319-325.

40. Uysalol M, Mutlu LC, Saracoglu GV, Karasu E, Guzel S, Kayaoglu S, Uzel N. Childhood asthma and vitamin D deficiency in Turkey: is there cause and effect relationship between them? Ital J Pediatr 2013;39:78.

41. Rajabbik MH, Lotfi T, Alkhaled L, Fares M, El-Hajj Fuleihan G, Mroueh S, Akl EA. Association between low vitamin D levels and the diagnosis of asthma in children: a systematic review of cohort studies. Allergy Asthma Clin Immunol 2014;10(1):31.

42. Wjst M. The vitamin D slant on allergy. Pediatr Allergy Immunol 2006;17(7):477-483.

43. Lange NE, Litonjua A, Hawrylowicz CM, Weiss S. Vitamin D, the immune system and asthma. Expert Rev Clin Immunol 2009;5(6): 693-702.

44. Hyppönen E, Sovio U, Wjst M, Patel S, Pekkanen J, Hartikainen AL, Järvelinb MR. Infant vitamin D supplementation and allergic conditions in adulthood: northern Finland birth cohort 1966. Ann NY Acad Sci 2004;1037:84-95.

45. Castro M, King TS, Kunselman SJ, Cabana MD, Denlinger L, Holguin $\mathrm{F}$, et al. Effect of vitamin $\mathrm{D}_{3}$ on asthma treatment failures in adults with symptomatic asthma and lower vitamin D levels: the VIDA randomized clinical trial. JAMA 2014;311(20):2083-2091.

46. Iordanidou M, Paraskakis E, Giannakopoulou E, Tavridou A, Gentile G, Borro M, et al. Vitamin D receptor ApaI a allele is associated with better childhood asthma control and improvement in ability for daily activities. OMICS 2014;18(11):673-681. 